\title{
KONSERVASI KEARIFAN BUDAYA LOKAL DALAM PROSES INTERAKSI SOSIAL ETNIS MELAYU DI KABUPATEN BATU BARA
}

\author{
Ramli Nur \\ Universitas Negeri Medan, Indonesia \\ E-mail: ramli_nur2010@yahoo.com
}

\begin{abstract}
The article examines the local wisdoms of ethnic Malay in the district of Batu Bara as a reference for their individual and social interactions with special focus on interethnic relationships, particularly within socio-religious realm. The study finds that ethnic diversity in the district of Batu Bara is not an obstacle to create a harmonious relation in social, economic, political, and religious activities among the people. It means that the Malays in Batu Bara have virtuous interaction with other ethnicities in the region. They, for an instance, are able to build mutual trust with other ethnicities in economic activities. In addition, they are able to work hand-in-hand with other people in many areas of social aspects. It is also found that the Malays of Batu Bara treat other ethnicities as equal in terms of providing an individual his/her social stratum to be, for an example, a prominent figure of society. They also give other people from other ethnicities chance of being political elites or leaders of mass organizations. The study finds that, however, the Malays of Batu Bara tend to choose the local (indigenous) person as their leader.
\end{abstract}

Keywords: Social cohesion; local wisdom; social interaction.

\section{Pendahuluan}

Batu Bara merupakan salah satu kabupaten yang berada di Provinsi Sumatera Utara yang secara topografi wilayah masuk dalam kawasan pantai timur Sumatera Utara. ${ }^{1}$ Istilah Batu Bara mengacu kepada sekelompok orang yang memiliki ciri-ciri pengenal budaya yang sama dan mengaku sebagai penduduk yang berdomisili di

1 Tim Badan Pusat Statistik Kabupaten Batu Bara, Batu Bara dalam Angka 2015 (Batu Bara: BPS Kabupaten Batu Bara, 2015). 
Kabupaten Batu Bara. Masih terdapat multikajian mengenai siapa sebenarnya etnik asli Batu Bara dan bagaimana asal usulnya. Mayoritas pengkaji-yang terutama mendasarkan pada informasi yang tersedia dalam dokumen-dokumen sejak masa pemerintahan kolonial Belanda-berpendapat bahwa sebagai sebuah etnis, masyarakat Batu Bara baru terbentuk sekitar abad ke XVIII, sebagai hasil proses percampuran dan akulturasi antar-kelompok etnik di Batu Bara, baik melalui perkawinan maupun Perdagangan. Dapat dikatakan, dalam konfigurasi kependudukan, Batu Bara sekarang telah menjelma menjadi melting-pot, super market, atau—meminjam istilah Hatley_kuali besar (pendhulungan), ${ }^{2}$ tempat bertemunya aneka etnik, agama, dan kebudayaan dari berbagai daerah.

Kabupaten Batu Bara, sebagaimana wilayah-wilayah lain di Indonesia—dari segi agama, keyakinan, budaya, dan suku bangsaadalah salah satu contoh daerah Kabupaten yang paling beragam. Kenyataan secara niscaya menunjukkan bahwa Kabupaten Batu Bara, dihuni oleh beragam etnik, budaya, dan agama yang keberadaannya diakui oleh negara dan menjadi anutan bagi umat masing-masing dalam melakukan aktivitas kehidupan sosial keagamaan. Kemajemukan tersebut adalah kekayaan dan modal sosial (social capital) bangsa serta merupakan sumber kearifan yang luhur yang dapat menjadi perekat harmonisasi hubungan sosial sekaligus energi pengikat yang membaurkan berbagai elemen masyarakat yang heterogen. ${ }^{3}$

Dalam konteks masyarakat Batu Bara yang multikultur, kearifan budaya lokal harus digali, dikonservasi, didayagunakan dan dikaji ulang secara mendalam. Kearifan budaya lokal sebagai sebuah produk totalitas suku (atau multisuku), pasti sudah pernah teruji eksistensi dan relevansinya. Sebagai sebuah produk totalitas atau budaya suku,

${ }^{2}$ Istilah Pendalungan ini berasal dari istilah yang dipergunakan Ron Hatley (1984) dalam monografnya yang berjudul "Mapping Cultural Regions of Java". Lihat Kusnadi, "Masyarakat Tapal Kuda: Konstruksi Kebudayaan dan Kekerasan Politik", Jurnal Ilmu-ilmu Humaniora, Vol. 2, No. 2 (Juli, 2001), 2.

3 Lihat Tim Forum Komunikasi Umat Beragama Sumatera Utara, "Kerangka Acuan: "Dialog Urgensi Aktualisasi Pendidikan Multikultural dalam Membangun Kerukunan Antar Umat Beragama”, Makalah disampaikan pada seminar Dialog Urgensi Aktualisasi Pendidikan Multikultural dalam Membangun Kerukunan Antarumat Beragama, di Medan, 17 Oktober 2009. Tentang ini lihat juga, Nur Ahmad Fadhil Lubis, "Multikulturalisme dan Persinggungannya dengan Agama dan Umat Islam", Jurnal Kerukunan: Kerukunan Berbasis Multukultural (Oktober-Desember 2008), 11. 
kearifan budaya lokal memiliki hubungan dengan semua aspekaspeknya, seperti sistem kemasyarakatan, sistem nilai atau sistem religi, dan mungkin juga berhubungan dengan sistem ekonomi atau mata pencaharian, seni dan seterusnya. Sebagai produk totalitas, maka kebersamaan menjadi nilai utama yang senantiasa harus diperjuangkan atau dijaga dengan jiwa bersama.

Dalam meresolusi keragaman, kearifan budaya lokal dipandang memiliki daya guna, kekuatan, dan kontribusi yang lebih efektif untuk mengatasi dan menyelesaikannya. Kesimpulan ini mengacu pada esensi kearifan budaya lokal sebagai tradisi yang pernah hidup, inheren dan terpelihara dengan baik serta dinilai mampu mengatur interaksi-interaksi sosial di dalam kelompok internal maupun maupun hubungan antarkelompok.

Dalam upaya pengarustamaan peran kearifan budaya lokal dalam mengelola, menegosiasi dan meresolusi keberagaman di Kabupaten Batu Bara, maka dilakukan penelitian di wilayah ini, khususnya kearifan budaya lokal yang hidup dan didayagunakan di kalangan etnis Melayu. Kertas kerja ini berupaya mengetahui bagaimana kehidupan masyarakat Melayu Batu Bara yang masih bertahan dengan budaya lokalnya, baik dalam kehidupan beragama, maupun kehidupan sosialnya. ${ }^{4}$ Selanjutnya dilihat juga peran, fungsi, dan upaya pranata dan lembaga lokal dalam usaha transmisi kearifan budaya lokal dan pembentukan pola dan proses interaksi sosial keagamaan yang harmonis, rukun dan damai antar-etnis di Batu Bara.

\section{Kearifan Lokal Etnis Melayu Batu Bara}

Sifat-sifat orang Melayu Batu Bara sering dibicarakan dalam berbagai kesempatan, yaitu yang tingkah lakunya lemah lembut, ramah-tamah, mengutamakan sopan santun, dan menghormati tamu. Hal ini menjadi relevan bila dikaitkan dengan adanya pengaruhpengaruh dari luar sejumlah migran yang mengunjungi daerah pesisir

\footnotetext{
${ }^{4}$ Di Kabupaten Batu Bara muncul beberapa konflik dalam kegiatan dan pelaksanaan budaya lokal, misalnya, dalam ritual budaya "Jamu Laut", sebagian kalangan menganggap ritual tersebut telah menodai kemurnian agama, karena masih mengandung unsur-unsur animisme, dinamisme dan paham syirik. Bagi kalangan yang lain menganggap justru merupakan warisan kearifan dari budaya leluhur yang harus dilestarikan. Sebagai sebuah kabupaten yang sedang membangun, persoalan tersebut, bila tidak direspons dan dikelola secara tepat, profesional dan kompeten oleh pihak-pihak terkait, khususnya Kementerian Agama, dapat menjadi benihbenih konflik, yang dapat menghambat harmonisasi kehidupan sosial keagamaan dan perkembangan pembangunan daerah.
} 
yang dihuni mereka. Kepentingan dagang menghendaki orang Melayu menciptakan suasana kepatuhan hukum, mereka pemberani, perajin dan mementingkan keharmonisan dalam melaksanakan mata pencaharian mereka. Kesemuanya sejalan dengan ajaran dan prinsip agama Islam yang dianut. ${ }^{5}$

Melayu bukan hanya identitas diri namun dapat pula berarti pandangan hidup. Melayu dapat dikategorikan sebagai sebuah konsep atau kaca pandang yang bersifat mendasar tentang diri dan dunia yang menjadi panduan untuk meraih kehidupan yang bermakna. Kaca pandang tersebut berfungsi sebagai sarana untuk merespons dan menerangkan permasalahan eksistensial kehidupan seperti, Tuhan, manusia, dan dunia (alam semesta). Melayu adalah identitas kultural namun inklusif dan dapat mengadopsi dari berbagai kebudayaan yang berada di luar Melayu Batu Bara, tentunya yang sesuai dengan identitas dan kepribadian masyarakat Batu Bara. Melayu ibarat rumah yang di dalamnya dihuni oleh berbagai orang dengan berbagai kaca pandang yang beragam, keberbagaian tersebut dapat bersumber dari keragaman agama maupun etnis dan kebudayaan.

Ada beberapa sifat orang Melayu yang harus ada pada diri orang Melayu, seperti:

a. Sifat tahu asal kejadian, yakni setia dalam agama, takwa kepada Tuhan yang Maha Esa serta kokoh dalam amal ibadah sifat ini tercermin dalam ungkapan: yang agama berkelakuan, yang iman berketeguhan, yang sujud berkeekalan, dan yang amal berkepanjangan.

b. Sifat hidup memegang amanah, yakni sifat ksatria, setia dan dapat dipercaya, tercermin seperti dalam ungkapan: Taat pada petuah, setia pada sumpah, mati pada janji, melarat pada budi.

c. Sifat benang, yakni sifat lurus, jujur setara kulit dengan isi, seperti tercermin dalam ungkapan: "Sepadan laku dengan buatnya, sepadan cakap dengan perangainya."

d. Sifat tahu kelak dengan elak, yakni sifat arif dan bijaksana, seperti tergambar dalam ungkapan: "Cepat akal laju pikiran, cepat angan laju buatan".

e. Sifat yang bersifat, yakni sifat menjunjung tinggi nilai-nilai agama, budaya dan norma-norma dalam masyarakat, tercermin dalam

5 Lihat Muhammad Takari dan Heristina Dewi, Budaya Musik dan Tari Melayu Sumatera Utara (Medan: USU Press, 2008), 49. 
ungkapan seperti: Menjunjung shara' dengan adatnya, menjunjung undang dengan tuahnya, menjunjung tahu dengan ilmunya ${ }^{6}$

f. Sifat tahu membayar utang. Maksudnya, membalas dan mengenang budi baik seseorang.

g. Sifat tahu akan bodoh diri. Maksudnya, menyadari kekurangan serta menghargai kelebihan kelebihan orang lain. ${ }^{7}$

h. Sifat tahu diri. Maksudnya, sadar hidup di dunia dan akhirat kelak. $^{8}$

Adapun filosofi hidup orang Melayu itu "adat bersendi shara: Shara 'bersendi kitabullah". 'Sebagai orang Melayu atau orang yang telah merasakan dirinya orang Melayu harus menyadari dirinya dalam kedudukan sebagai warga masyarakat Islam yang mengarahkan tatanan dan ketentuan kehidupannya pada norma-norma Qur'ani serta berakidah Islam.

Manusia-manusia dalam masyarakat Melayu Batu Bara yang "walaupun berbeda status sosial, kedudukan, jabatan, latar belakang pendidikan, kekayaan, dan sebagainya harus memiliki kesatuan pandang dan sikap dan dilandasi rasa saling menghormati dan saling menghargai yang semua ini berakar dan bermuara dari nilai dan norma Islam. Nilai-nilai ajaran agama Islam yang dominan dalam filosofi orang Melayu sesungguhnya menghendaki orang Melayu berupaya menjadi manusia yang selalu tabah, tawakal, bertauhid, berserah diri dan memohon bantuan dan tawâdu', rendah hati dan menjauhi sifat sombong dan takabur". ${ }^{10}$

Hal di atas menggambarkan filosofi hidup orang Melayu Batu Bara "yang perbuatan dan kelakuannya biasanya adalah pertengahan dan tidak ingin menonjolkan diri, walaupun ada kesanggupan dan keahliannya. Ia tertib dan sopan dalam bahasa dalam makan minum, dalam perjalanan dalam kehidupan sehari-hari. ${ }^{11}$ Inilah salah satu pangkal filosofi orang Melayu yang terus diamalkan sampai sekarang.

${ }^{6}$ T. Amin Ridwan, Budaya Melayu Menghadapi Globalisasi (Medan: USU Press, 2005), 7.

${ }^{7}$ Ibid.

${ }^{8}$ Lebih lanjut kajian tentang sifat-sifat dan tingkah laku orang Melayu, lihat Lauraent Mametzger, Kekuatan dan Kelemahan Orang Melayu: Suatu Pandangan Seorang Asing (Kuala Lumpur: Akademi Pengkajian Melayu University Malaya, 1994), 7.

${ }_{9}$ Ridwan, Budaya Melayu, 113.

${ }^{10}$ Muchlis (Guru Agama), Wawancara, Lima Laras, Batu Bara, 15 September 2015.

11 Sulaiman Muhammad Amir (Cendekiawan Melayu Batu Bara), Wawancara, Lima Puluh, Batu Bara 16 September 2015). 
Etnis Melayu Batu Bara termasuk etnis yang berkembang pesat dan menerima keberadaan orang luar untuk masuk dalam kelompoknya. Hal ini berlangsung sesuai dengan falsafah hidup orang Melayu sendiri yang tertuang dalam lima dasar, yaitu: pertama, Melayu itu Islam yang sifatnya universal, demokratis, dan senang bermusyawarah; kedua, Melayu itu berbudaya yang sifatnya nasional dalam berbahasa, sastra, tari, pakaian, tersusun dalam tingkah laku, dan lain sebagainya; ketiga, Melayu itu beradat yang sifatnya regional (kedaerahan) dalam Bineka Tunggal Ika, dengan tepung tawar, balai pulut kuning, dan lain-lain yang mengikat kaum tua dan muda; keempat, Melayu itu berturai, yaitu tersusun dalam masyarakat yang rukun tertib (sosial order), mengutamakan ketenteraman dan kerukunan, hidup berdampingan dengan harga menghargai secara timbal balik, bebas tapi terikat dalam nilai-nilai sosial kemasyarakatan; Kelima, Melayu itu berilmu, artinya pribadi yang diarahkan pada ilmu pengetahuan dan ilmu kebatinan agar bermarwah dan disegani oleh banyak orang untuk kebaikan umum. Kalau salah satu dari unsur tersebut tidak dipunyai lagi, maka dia menjadi "layu" bukan lagi seorang Melayu asli.

Di balik itu semua, orang-orang Melayu Batu Bara sebagai etnis lokal Kabupaten Batu Bara memiliki adat budaya yang kaya dengan ragam kearifan yang menjadi ciri khas mereka. Sebagai masyarakat yang berbudaya, mereka tetap teguh mempertahankan dan melaksanakan kearifan tersebut. Bahkan beberapa tradisi budaya lokal Melayu Batu Bara banyak diadopsi oleh etnis lain. Sebagai sebuah etnis yang kaya dengan adat tradisi, etnis atau masyarakat Melayu Batu Bara memiliki beberapa kearifan budaya lokal yang mengandung nilainilai keharmonisan, rukun, dan persudaraan yang dapat diwujudkan dalam proses interaksi intra orang Melayu maupun antar-kelompok dari etnis lain. Di antara kearifan budaya lokal tersebut, yaitu:

\section{Ritual Bergito}

Bergito sendiri merupakan acara adat dalam "mengangkat saudara" yang terdapat dalam masyarakat Melayu. Kata Gito sendiri berasal dari Gita (Sanksekerta) yang bermakna nyanyian atau lagu. Setiap perhelatan pengangkatan atau pengakuan saudara dilakukan dengan acara dendang atau nyanyian lagu pujian-pujian yang intinya mengharapkan agar peserta upacara dalam keadaan sehat, selamat, dan sejahtera. 
Pelaksanaan pengangkatan saudara dilaksanakan dengan berbagai cara. Ada dengan bertukar darah, di mana masing-masing menusuk jarinya kemudian saling menempelkan darah yang keluar sebagai tanda sehidup-semati, dunia-akhirat. Ada juga dengan cara meneteskan darah ke dalam mangkuk. Kemudian darah tersebut diaduk bersamasama lalu disiram ke badan atau bahkan diminum seteguk seorang.

Cara lain pengangkatan saudara adalah dengan menempatkan kedua belah pihak yang Bergito duduk di atas satu tikar, satu bantal atau disebut juga "selapik seketiduran, sebantal setali darah". Kemudian keduanya mengucapkan sumpah Pergitoan yang intinya kedua belah pihak sudah mengangkat sumpah sebagai saudara. Apabila sudah bergito, maka persaudaraan menjadi kokoh sebagaimana dikatakan sebuah ungkapan: "Apabila sudah bergito, yang jauh menjadi dekat, yang renggang menjadi rapat, yang kawan menjadi kerabat, yang saudara menjadi erat", atau dikatakan "apabila gito sudah diikat disitulah saudara dunia akhirat".

Menurut Habibi, ${ }^{12}$ salah seorang penggiat budaya Melayu di Batu Bara, menyebutkan, upacara adat Gito sudah menjadi adat yang diwariskan turun-temurun oleh para leluhur. Acara adat itu tidak saja dilakukan kalangan rakyat biasa tetapi juga oleh para raja dan pembesar kerajaan.

Bagi "saudara Gito" yang sudah diresmikan secara adat terdapat beberapa pantangan. Pantang larang itu antara lain pantang aniayamenganiaya, pantang usik-mengusik, pantang buruk-memburukkan, pantang iri-mengiri, pantang dengki-mendengki, dan seterusnya. Sebaliknya kedua belah pihak diwajibkan saling membantu, mengingatkan, tolong-menolong baik ketika senang maupun susah. Dalam ungkapan adat dikatakan: Hidup seaib dan semalu, bidup senasib dan sepenanggungan, seiya sekato muka belakang, tolong-menolong tiada berkelang. Sesama saudara Gito tidak boleh kawin-mengawini (menikah). Jika terpaksa, hendaknya ditebus dengan tebusan sesuai dengan hukum adat yang berlaku dimasyarakat itu.

Inilah salah satu kearifan lokal masyarakat Melayu di Batu Bara yang mengandung nilai kerukunan yang tidak hanya terbatas pada sosok individu, tapi dapat menyatukan seluruh anggota masyarakat terutama ketika telah dilaksanakan bergito antara tokoh masyarakat. Tokoh tersebut menyatukan masyarakat yang ia pimpin dengan

${ }^{12}$ Habibi (penggiat budaya Melayu Batu Bara), Wawancara, Desa Lima Puluh Batu Bara 11 Oktober 2015. 
masyarakat saudara pergito-annya. Jadi, upacara pengangkatan saudara Gito merupakan salah satu wadah untuk mempererat hubungan dan mewujudkan kerukunan antara anggota masyarakat maupun antarsuku dan etnis berbeda sehingga tercipta masyarakat yang aman dan sejahtera yang dilandasi solidaritas antar-sesama.

\section{Budaya Persebatian dan Serayaan}

Dalam masyarakat Melayu Batu Bara dikenal suatu pandangan hidup bermasyarakat yang dikenal dengan Persebatian. Kearifan lokal ini bermakna persatuan dan kesatuan yang harus dijadikan nilai asas dalam merancang kegiatan kemasyarakatan yang dapat melibatkan seluruh anggota masyarakat Melayu, kelompok etnis lain, dan pemeluk agama. Dari Persebatian ini muncul sikap dan rasa tanggung jawab bersama dan kegotongroyongan dalam aktivitas bersama di tengahtengah masyarakat. Pemuka Adat Melayu Batu Bara menyatakan: dalam Persebatian, beban berat menjadi ringan; apabila bekerja bersama-sama, yang sulit menjadi mudah; jika bekerja beramai-ramai, tak ada kerja yang tak selesai; apabila kerja bersatu hati, faedahnya besar berjaya negeri. ${ }^{13}$

Wujud kegotongroyongan masyarakat dalam Persebatian (persatuan dan kesatuan) diungkap dengan istilah: betobo, besolang, bepiari, dan betayan. Istilah betopo mengandung makna "yang berat menjadi ringan, yang sulit menjadi mudah"; makna besolang adalah bahwa "yang sempit menjadi lapang; makna bepiari, yang beban sama dipikul, yang hutang sama dilunasi; dan makna betayan, yang sakit sama dirasakan, yang susah sama ditanggung. ${ }^{14}$ Dengan asas ini pula masyarakat Melayu dahulu dapat membangun dan membina kampung dan desanya dengan makmur, aman, dan rukun.

Sistem gotong royong selalu dilaksanakan oleh masyarakat Melayu Batu Bara dalam kegiatan di sawah, menanam padi dan membangun rumah. Dalam kegiatan di sawah dikenal dengan istilah serayaan, yaitu kerja seraya dalam menukar padi, mengetam padi, membawa padi ke rumah dan mengirik padi secara bersama-sama dengan melibatkan seluruh anggota masyarakat baik sesama orang Melayu juga dari etnis lain yang menetap di satu desa. ${ }^{15}$

\footnotetext{
${ }^{13}$ H. Sofyan (Ketua Dewan Pertimbangan Forum Komunikasi Antarlembaga Adat Kabupaten Batu Bara), Wawancara, Tanjung Tiram 14 Oktober 2015.

14 Ibid.

15 Ibid.
} 
Nilai Persebatian sangat penting dalam merealisir harmoni antarsesama anggota masyarakat, antarsuku, antargolongan, bahkan antar-agama. Misalnya, masyarakat Batu Bara telah membangun sebuah organisasi Melayu Batu Bara di bawah pimpinan Aslan Hamzah organisasi ini hampir dalam setiap aktivitasnya melaksanakan nilai-nilai Persebatian.

Dari sisi lain, nilai Persebatian dapat meningkatkan ketahanan bangsa, ketangguhan masyarakat dalam menghadapi berbagai masalah, seperti konflik antar-suku maupun agama yang dapat mengancam keutuhan dan persatuan bangsa dan Negara. Dari nilai Persebatian ini, masyarakat akan memiliki kesadaran bahwa mereka bersaudara, sehingga tidak akan mudah diprovokasi oleh pihak luar yang ingin merusak keharmonisan kehidupan masyarakat.

\section{Pantun Nasihat Pengembang Harmonisasi}

Etnis Melayu Batu Bara, terkenal dan identik sebagai etnis yang kaya dengan folklore lisan yang tertuang dalam bentuk pantun dan syair. Pantun dan syair ini mengandung makna yang tinggi, enak didengar, dan indah kata-katanya. Isi dan syair memiliki tujuan, nilai, dan ajaran yang merupakan refleksi dan deskripsi identitas serta realitas yang terjadi di masyarakat Melayu. Ada banyak jenis pantun dan syair yang berkembang di masyarakat, di antaranya pantun nasihat dan pantun tunjuk ajar.

Pantun nasihat digunakan sebagai media untuk menyampaikan pesan-pesan moral di tengah-tengah masyarakat, misalnya oleh orang tua pada anaknya, para pemimpin pada bawahannya, para guru untuk muridnya ataupun antar-anggota masyarakat dalam interaksi seharihari. Melalui pantun nasihat, nilai-nilai luhur dalam ajaran agama dan adat budaya diwariskan secara lisan kepada generasi muda dan seluruh warga masyarakat. Melalui pantun nasihat ini juga, nilai-nilai luhur direalisasikan dalam kehidupan sehari-hari. Secara ringkas fungsi pantun nasihat tergambar dalam ungkapan: dengan pantun banyak yang dituntun; pantun dipakai memperbaiki perangai; pantun mengajar bersopan santun; melalui pantun syarak menuntun. ${ }^{16}$

Pemakaian pantun nasihat tidak terbatas tempat dan waktu, dilakukan setiap saat sesuai dengan fungsinya. Misalnya, pantun nasihat dipakai dalam nyanyian, upacara ritual adat, percakapan seharihari. Tradisi berbalas pantun memiliki nilai kearifan yang tinggi untuk diterapkan di tengah-tengah masyarakat. Kata-kata yang terangkai

${ }^{16}$ Ibid. 
dalam sebuah pantun dibuat berdasarkan tujuan tertentu. Selain itu terdapat suatu persayaratan di kalangan orang Melayu bahwa siapa yang menyampaikan pantun, maka ia harus memiliki sikap dan tingkah laku sesuai dengan kandungan nilai pantun yang ia sampaikan.

Secara tidak langsung, sebuah pantun menunjukkan suatu kualitas moral si penyampai dan isi pantun merefleksikan kepribadiannya. Akhirnya, tidak akan terdapat suatu penegasian dari kalangan masyarakat ketika sebuah pantun itu dibacakan oleh orang yang memiliki kepribadian yang sejalan dengan isi pantun. Oleh karena itu, kearifan yang tampak dalam sebuah pantun sangat berperan dalam membentuk kualitas masyarakat. Ketika seorang membaca pantun nasihat yang berisikan pesan-pesan kebersamaan, toleransi, persaudaraan, dan nilai kearifan lainnya, maka masyarakat akan mencoba menyerap dan merealisasikan dalam kehidupan mereka.

Orang-orang Melayu sering membacakan pantun yang mengungkapkan identitas mereka sebagai orang yang berbudi, sopan santun dan berakhlak mulia. Seperti pantun: Biarlah orang bertanam buluh, kita bertanam padi juga, biarlah orang bertanam musuh, kita bertanam budi jua; Kalau kita bertanam padi, senanglah makan adike beradik, kalau kita bertanam budi, orang yang jahat menjadi baik; Kalau keladi sudah ditanam, janganlah lagi meminta talas, kalau budi sudah ditanam, janganlah lagi minta dibalas; Kalau makan keladi muyang, jangan lupa pada bungkalnya, kalau kemakan pada budi orang, jangan lupa pada asalnya; Jangan suka mencabut padi, kalau dicabut bilang buabnya, jangan suka menyebut budi, kalau disebut bilang tuahnya; Mati kayu karena benalu, patabnya layu dahannya mati, matilah melau, karena termakan budi; Biarlah orang mencabut cendawan, kita cabut pada akan mati, biar orang berbuat hartawan, kita berbuat budi pekerti; Hidup dalam pekerti, mati dalam budi; Tabu budi ada butangnya, tabu bidup ada bebannya. ${ }^{17}$

Syair dan pantun budi di atas menegakan bahwa orang-orang Melayu Batu Bara memiliki kearifan yang tinggi dalam berhubungan dan berinteraksi dengan sesama dan pihak luar. Seorang Melayu akan bergaul dan membina hubungan harmonis, memberikan sesuatu yang bermanfaat bagi diri dan kehidupan orang lain. Secara sadar, orang Melayu Batu Bara menginginkan hidupnya damai dan tenteram serta berusaha menghindari permusuhan terutama dengan pihak luar.

Beberapa pantun lain yang mengandung ajakan untuk menjauhi konflik dan mewujudkan harmonisasi, seperti: Jangan suka nak merapah

${ }^{17}$ Ibid. 
pagar' merapah pagar kaki terpuruk, jangan suka nak berkata kasar, berkata kasar budinya buruk; Jangan suka menetak rebong, rebung itu banyak. bulunya, jangan suka berlagak sombong, sombong itu banyak musubnya; Elok-eloklah merendang cendawan, basah sedikit rending tak jadi, elok-eloklah menenggang kawan, salah sedikit jangan peduli; Kalau pandai merendang cendawan, rending dimakan terasa nikmat, kalau pandai menenggang kawan, orang senang nak. bidup selamat, Jangan suka mandi berendam, lama-lama tak bisa bangkit, jangan suka menyimpan dendam, lama-lama jadi penyakit. ${ }^{18}$

Pantun-pantun di atas menganjurkan agar setiap orang membina hubungan dengan orang lain secara baik dan arif. Tidak berkata kasar, bersikap sombong, berbuat buruk yang dapat menyulut api permusuhan. Jika seseorang berbuat salah hendaknya kita dapat memaafkan karena hidup terasa lebih nikmat ketika tidak ada konflik dan perselisihan.

Bagaimana ketika orang-orang Melayu Batu Bara menghadapi suatu persoalan, perselisihan pendapat dalam interaksi dalam kehidupan bermasyarakat? Beberapa pantun Melayu menjawab pertanyaan tersebut. Seperti pantun-pantun berikut: Air jernih sajaknya landau, jalan raya titian batu, berunding cerdik dengan pandai, paham dua menjadi satu; Putus gading karena dikerat, belum jatuh sudablab retak, putus runding karena mufakat, bukum jatuh karena terletak; Kalau ranting sudah bertangkai, jangan dililit-lilit juga, kalau berunding sudah selesai, jangan diungkit-ungkit jua. ${ }^{19}$

Pantun-pantun di atas menunjukkan bahwa orang Melayu memiliki kearifan dalam menyelesaikan kearifan dalam menyelesaikan perbedaan pendapat ataupun perselisihan. Apabila terdapat perbedaan pandangan, mereka akan membawa persoalan tersebut dalam forum musyawarah antar-warga untuk dicarikan pemecahannya. Ketika kesepakatan telah dicapai, setiap orang harus menerima dan tidak lagi mengungkap perbedaan tersebut.

4. Kearifan dalam Kepemimpinan Melayu

Dalam pandangan hidup orang Melayu Batu Bara, pemimpin merupakan sosok orang yang dituakan oleh kaum dan bangsanya, memiliki keteladanan, dan kepribadian yang tinggi. Dalam sebuah ungkapan dikatakan, pemimpin adalah: Yang didabulukan selangkah, yang ditinggikan seranting, yang dilebihkan serambut, yang dimuliakan sekutu. Ungkapan ini mengisyaratkan bahwa seorang pemimpin begitu dekat

\footnotetext{
${ }^{18}$ Ibid.

${ }^{19}$ Ibid.
} 
seakan-akan tiada jarak dengan masyarakatnya. Hubungan seorang pemimpin Melayu dengan masyarakatnya menyatu dan membaur tanpa ada hirarki yang jelas.

Dalam berbagai pepatah, pantun, dan syair orang Melayu, seorang pemimpin dalam etnis Melayu sangat berperan dalam mewujudkan keharmonisan, kerukunan, kedamaian, dan kesejahteraan seluruh masyarakatnya tanpa ada pengecualian. Peran dan fungsi pemimpin Melayu terungkap dalam banyak syair dan pantun Melayu, seperti: Bagaikan kayu besar di tengah padang, rimbun daunnya tempat berteduh, kuat dahannya tempat bergantung, kukuh batangnya tempat bersandar, besar akarnya tempat bersila; Yang jauh semua tampak, yang dekat mulia bersua, yang tinggi menahan angina, yang rendah menaban lapab; Rumabnya tempat beradat, tempat berunding bermufakat, tempat berhenti jaub dan dekat, tempat berbimpun kaum kerabat, tempat bersinggah taulan sahabat, tempat mengadu segala rakyat, Menegakekan syarat yang dipegang, menegakkean adat yang dipegang, menegakean amanah yang disandang, menegakkan bukum yang ditimbang, menegakkan pusaka yang berbilang, menegak.kan janji yang ditimang; Menjadi suluh dalam gulita, menjadi penawar penolak bias, menjadi penenang dalam duka, menjadi penyejuk dalam derita, menjadi penyabar dalam murka, menjadi benteng dusun dan kampong, menjadi pagar teluk dan tanjung; Karam dilaut jadi pelampung, panas di darat jadi penaung, basah di bilir jadi penudung, patah di bulu jadi penyambung. ${ }^{20}$

Ungkapan dan syair Melayu di atas menggambarkan bahwa pemimpin dalam etnis Melayu adalah sosok yang menaungi seluruh rakyat, menyalurkan aspirasi, menyatukan perbedaan, dan menyelesaikan setiap perselisihan dan pertikaian di kalangan masyarakat yang dipimpin. Seorang pemimpin melebur serta menyatu dengan selurh anggota masyarakat, baik yang kaya maupun miskin, yang lemah maupun yang kuat, dari etnis Melayu maupun dari etnis lain, dan yang seagama maupun bukan. Singkatnya, ketenteraman, keharmonisan, kedamaian, dan kerukunan di masyarakat Melayu Batu Bara berada di tangan sang pemimpin.

5. Kearifan dalam Penyelesaian Konflik

Di tengah gelombang globalisme dan liberalisme yang terus menggerus nilai-nilai dan identitas budaya lokal di hampir seluruh wilayah di Indonesia, masih ada kekuatan yang terus dijaga dan dipelihara untuk memperkuat teladan dan kearifan budaya di kalangan masyarakat adat Melayu. Masyarakat Melayu Batu Bara, sebagaimana

${ }^{20}$ Ibid. 
dinyatakan di atas, identitas tradisi dan kebudayaannya berinduk pada tradisi dan kebudayaan Melayu Sumatera Timur. Di daerah ini, masyarakat Melayu memiliki sebuah kearifan menyelesaikan konflik dan pertikaian melalui pendekatan kekerabatan dan kebersamaan yang sangat luhur. Kearifan budaya tersebut di antaranya menggunakan media tepung tawar dalam meresolusi konflik yang disebut dengan upacara punjung mentah dan tepung tawar. Menurut Muklis, apabila ada konflik, perselisihan dan kekerasan yang saling melukai satu sama lain, dengan menggunakan tradisi tepung tawar itu, di antara orang yang bertikai dapat saling berdamai dan akur kembali. ${ }^{21}$

Punjung mentah merupakan alat atau sarana untuk penyelesaian konflik antara dua kelompok/individu. Dalam pelaksanaannya, pihak yang bersalah harus membawa punjung mentah berupa kopi, gula dan beras dua kilo gram, seekor ayam dan sebungkus rokok kepada keluarga korban atau yang tidak bersalah dalam konflik tersebut. Punjung mentah itu sebagai bentuk ungkapan penyesalan dan permohonan maaf kepada keluarga korban. Kalau sudah punjung mentah ini dibawa, biasanya keluarga korban merasa puas dan dihormati dan langsung menerima ungkapan maaf itu dengan lapang dada tanpa ada dendam. Usai pemberian punjung mentah, kemudian dilanjutkan dengan tradisi tepung tawar, orang yang saling bertikai itu kemudian saling mengoleskan tepung tawar di badannya. Sesudah itu, kedua orang yang bertikai tadi sudah dianggap menjadi bagian dari saudaranya sendiri. Usai melakukan tradisi punjung mentah dan tepung tawar, konflik yang terjadi diharapkan menjadi damai.

Menurut Habibi, pemangku adat dan budaya dalam masyarakat Melayu memiliki peranan sangat penting dalam penyelesaian konflik di kalangan masyarakatnya. Pemangku adat selalu dijadikan agen perdamaian bagi mereka yang berkonflik. Dengan melakukan negosiasi, akhirnya disepakati untuk melaksanakan upacara punjung mentah dan tepung tawar. ${ }^{22}$ Bagi mereka, tidak seluruh konflik harus diselesaikan secara hukum. Masyarakat Melayu memiliki kearifan yang sangat berguna dalam menyelesaikan pertikaian dan perselisihan dengan cara damai. Seorang tokoh Melayu mengatakan: "kalau semua konflik harus diselesaikan secara hukum, konfliknya makin tak terurus. Selain karena aparat negara lambat, masyarakat juga kurang

\footnotetext{
${ }^{21}$ Mukhlis (Guru Agama), Wawancara, Lima Laras, Batu Bara 16 Oktober 2015.

${ }^{22}$ Habibi, Wawancara, Lima Puluh 11 Oktober 2015.
} 
puas. Hasilnya jauh lebih ampuh dengan pendekatan dan pendayagunaan nilai adat dan kearifan budaya lokal". ${ }^{23}$

Upacara adat tepung tawar merupakan adat tradisi Melayu yang berorientasi pada penetralisiran semangat atau keinginan negatif penyebab perpecahan dan merestorasi kedamaian. Beras putih yang disemai di tanah kemudian ditabur dalam upacara tersebut merepresentasikan "undangan" bagi semangat kesucian untuk menebari bumi yang terkoyak konflik.

Media tepung tawar ini tidak hanya berlaku bagi komunitas yang seidentitas budaya saja, tetapi juga dapat dilakukan oleh orang luar yang kebetulan sedang berselisih paham atau berkonflik dengan orang adat Melayu. Memang seolah sulit dinalar, karena praktik demikian sangat menyentuh emosi, rasa, nurani, dan kehormatan diri. Ketika budaya itu diangkat, diakomodasi dan dijunjung tinggi, maka sang pelaku budaya itu pun merasa harga diri dan ideologinya dihormati. Sebaliknya, bila tradisi itu ditanggalkan atau diabaikan apalagi dilecehkan, perlawanan pun dapat muncul secara spontan dan sporadis yang dapat mengobarkan konflik komunitas yang dahsyat.

\section{Dinamika Pembauran dan Proses Interaksi Sosial}

Keterbukaan masyarakat Batu Bara terhadap etnis pendatang, akar genealoginya dapat diruntut sejak masa kolonialisme. Perkembangan perkebunan besar di Batu Bara telah merubah kawasan ini dari tempat yang sepi dan jarang penduduk menjadi tempat ramai sekaligus berpengaruh terhadap pertumbuhan dan penyebaran komposisi penduduk serta proses integrasi. Satu hal yang perlu dicermati bahwa sangat sedikit penduduk lokal yang bersedia menjadi buruh perkebunan. Karena itu, tenaga kerja di perkebunan kebanyakan berasal dari luar Batu Bara, seperti Jawa, Keling, dan Batak. Pembauran suku-suku bangsa di daerah perkebunan dan pelabuhan mengakibatkan dibutuhkannya sarana komunikasi. Bahasa Melayu ternyata dapat diterima sebagai jalan "kompromi" dalam komunikasi antaretnis yang ada di Sumatera Timur pada waktu itu.

Salah satu alasan mengapa daerah Melayu Batu Bara mampu menjadi daerah yang kaya akan keragaman dalam bidang sosial budaya berawal dari masyarakat Melayu di daerah ini. Masyarakat Melayu sebagai penduduk asli Kabupaten Batu Bara adalah masyarakat yang terbuka bagi masyarakat di luar daerahnya tanpa memandang sesuatu

23 Bachtiar Effendi (Wakil Ketua Pengurus Harian Forum Komunikasi Antar Lembaga Adat Kabupaten Batu Bara), Wawancara, Pantai Bunga 14 Oktober 2015. 
apapun. Orang Melayu tidak pernah menyoal asal-usul keturunan atau etnik orang lain untuk menjadi Melayu, karena yang diperlukan adalah kesamaan budaya (adat resam). Usman Pelly menyatakan kelompok etnik Melayu lebih menekankan faktor-faktor sosial budaya. Apakah seseorang berasal dari keturunan Cina, Arab, India, Jawa, atau Batak, selama dia memenuhi kelima faktor-faktor berikut: beragama Islam, berbahasa Melayu, beradat resam Melayu, tinggal di kawasan Melayu, dan mengaku Melayu, maka dia disebut dan diakui Melayu. Dari segi struktur, etnik Melayu berbeda dengan etnik-etnik lainnya di Nusantara.

Keterbukaan masyarakat Melayu ini dapat juga dilihat dari sistem budaya yang dimilikinya. Salah satu parameter yang dapat digunakan adalah dalam aspek budaya seni. Kesenian masyarakat Melayu mampu menerima instrumen-instrumen dari luar daerahnya seperti biola dan akordeon yang bukan instrument asli dari daerah ini melainkan dari masyarakat Eropa yang melakukan kontak terhadap masyarakat Melayu. Di dalam seni pertunjukkan Melayu juga terdapat unsur heterogenitas budaya, akulturasi, pemungsiannya pada segenap strata sosial, dan lain-lain.

Sekalipun budaya Melayu cukup terbuka pada perubahan, namun mereka sangat menyadari pembedaan antara adat asli dengan yang baru. Karena itu, etnis Melayu ini dalam konteks kebijakannya menghadapi kontinuitas kebudayaan, menggunakan empat klasifikasi adat: 1) adat yang sebenarnya adat, yaitu hkum alam yang secara turun-temurun harus terjadi menurut waktu dan ruang yang jika dikurangi merusak, dan jika dilebihi mubazir; 2) adat yang diadatkan, yaitu adat yang berasal dari musyawarah dan mufakat masyarakatnya yang dipercayakan kepada para pemimpinnya; 3) adat yang teradat, yaitu kebiasaan-kebiasaan yang lama kelamaan atau tiba-tiba menjadi adat; dan 4) adat istiadat, yaitu adat yang merupakan kumpulan dari berbagai-bagai kebiasaan, dan cenderung diartikan sebagai upacaraupacara khusus.

Banyak orang pedalaman Sumatera Timur, misalnya Batak, yang migrasi ke wilayah pesisir Melayu. Para perantau Halak Batak yang menetap di daerah tanah Melayu kemudian mengadopsi budaya Melayu dan agama Islam dalam kehidupan kesehariannya. Mereka membuang marga Bataknya dan benar-benar membaur menjadi suku Melayu selama beberapa generasi. Para perantau Batak dan keturunannya yang menjadi Melayu inilah kemudian di Batu Bara 
disebut sebagai "Melayu Batak" (pada Melayu Deli proses absorpsi (penyerapan) ini menghasilkan penyebutan "Batak Dalle"). Orangorang Melayu baru ini diterima pada tahap-tahap awal sebagai "Melayu Dusun" dan kemudian setelah ada tenggang masa sosialisasi baru dianggap sebagai Melayu sesungguhnya, sama dan sederajat dengan Melayu lainnya. Termasuk hak-hak mereka seperti hak untuk mendapatkan perlindungan Sultan, gelar kehormatan seperti gelar Datuk sebagai kepala wilayah, atau hak untuk mendapatkan tanah ulayat. $^{24}$ Selama berabad-abad orang-orang Batak yang menjadi Melayu ini membuang marga Bataknya, dan bahkan banyak generasi mudanya yang tidak mengerti asal-usulnya. ${ }^{25}$

Mungkin yang tidak benar-benar menjadi Melayu, terutama dari segi budayanya, adalah etnis Jawa. Sekalipun demikian, kontak antara masyarakat Jawa dan Melayu sering terjadi karena tidak ada lagi batas antara masyarakat Jawa dengan masyarakat lainnya di Batu Bara. Hubungan yang semakin kuat antara masyarakat Jawa, Melayu, dan masyarakat lainnya diawali ketika zaman perjuangan kemerdekaan, hingga zaman mempertahankan kemerdekaan. Tokoh-tokoh pergerakan nasional yang mempertahankan kemerdekaan di daerah Batu Bara tidak lagi hanya didominasi oleh masyarakat asli daerah ini saja seperti masyarakat Melayu dan Batak, tetapi juga masyarakat di luar masyarakat asli daerah ini, seperti masyarakat Jawa. Hubungan ini terus berlanjut hingga zaman perjuangan kemerdekaan berakhir.

Hubungan antara masyarakat Jawa dengan masyarakat lainnya tidak hanya sebatas perjuangan kemerdekaan saja tetapi sudah ke bidang-bidang lainnya. Masyarakat Jawa dan masyarakat lainnya juga melakukan hubungan seperti dalam hubungan budaya. Setelah zaman perjuangan kemerdekaan berakhir masyarakat Jawa banyak yang menekuni bidang seperti bidang seni dan budaya. Yang paling menarik adalah masyarakat Jawa tersebut bukan hanya memainkan seni dan budayanya sendiri, tetapi juga ada yang memainkan seni dan budaya masyarakat Melayu. Ini dapat dilihat dari banyaknya pemain musik Melayu yang berdarah Jawa. Mereka mendapatkan pengaruh ini

\footnotetext{
${ }^{24}$ Usman Pelly, “Siapakah Orang Melayu Itu?”, Republika, 27 Juli 2002.

25 Belakangan, masyarakat Melayu Batak mulai menyadari asal-usul keluarganya. Pada tahun 1950 sampai sekarang, mulai banyak mereka yang kembali menggunakan marga Bataknya. Akan tetapi budaya, bahasa daerah asal (Batak) dan adat-istiadatnya yang sudah hilang selama beberapa generasi memang sukar untuk dikembalikan, sehingga mereka tetap diklasifikasikan sebagai Batak. Melayu.
} 
ketika musik Melayu masih popular dan sering dimainkan di daerahdaerah pemukiman masyarakat Jawa.

Selain nilai dan "keterbukaan", nilai yang juga sering disebut dalam konteks perbincangan tentang budaya Melayu Batu Bara adalah sikap lugas; kata-kata yang komunikatif, terus terang, langsung pada subjek pembicaraan, serta tindakan yang apa adanya. Sikap lugas dalam bertutur kata itu dimungkinkan karena struktur bahasa MelayuBatu Bara itu sendiri yang simpel dan non-hierarkis. Mengenai hal ini salah seorang informan mengatakan bahwa salah satu hal yang juga kerap menimbulkan kesan keliru mengenai budaya Batu Bara di mata orang luar adalah sikap terus terang orang Batu Bara. Diungkapkan bawah "orang Batu Bara cenderung bersikap apa adanya. Kalau dia tidak suka, maka dia langsung menunjukkan sikap ketidaksukaan itu. Itulah sebabnya mungkin hidup orang Batu Bara terkesan sering terlihat tidak akur antarsesama keluarga", papar informan tersebut. ${ }^{26}$ Berbeda dengan budaya lain, seperti Jawa misalnya, kalau seseorang tidak senang dengan sikap, perkataan atau perbuatan orang lain, dia cuma memendam perasaan tersebut. Karena itu, menurut informan tersebut, "Bisa jadi sikap orang itu berbeda antara apa yang dia tampakkan dan yang sesungguhnya dia rasakan", ${ }^{27}$

Dalam konteks keharmonisan dan kerukunan hidup antarumat beragama, sikap keterbukaan menjadi salah satu pilar penting dalam membangun suatu masyarakat yang majemuk, baik dari segi etnis, budaya maupun agama. Sementara itu, sikap lugas dan terus terang dapat menjadi modal dasar untuk menghilangkan prasangka antarkelompok, yang biasanya lahir dari sikap ketertutupan dan tidak terus terang.

\section{Sikap Toleran Terbatas}

Hampir seluruh pengamat budaya Melayu Sumatera Timur, dan kalangan komunitas Melayu Batu Bara sendiri, sepakat dengan pandangan bahwa identitas budaya Batu Bara tidak dapat dilepaskan dari elemen religiositas, khususnya keislaman. Dengan kata lain, keBatuBara-an nyaris identik dengan keislaman. Bahkan, berbeda dengan suku lainnya yang mengalami proses islamisasi setelah identitas kesukuan mereka terbentuk mapan, komunitas Batu Bara mengalami proses islamisasi dan pembentukan identitas kesukuan

\footnotetext{
26 Sulaiman Muhammad Amir (Cendekiawan Melayu Batu Bara), Wawancara, Lima Puluh, Batu Bara 18 September 2015.

${ }^{27}$ Ibid.
} 
secara hampir bersamaan. Dengan demikian, Islam turut menentukan corak identitas ke-Batu Bara-an mereka. Itulah sebabnya komunitas penganut non-Muslim yang secara terbuka mengidentikkan dirinya dengan Melayu Batu Bara dianggap suatu fenomena ganjil yang deviatif.

Soal identitas ke-BatuBara-an dengan keislaman mungkin tidak lagi menjadi pesoalan. Pertanyaan selanjutnya adalah apakah watak religius budaya Batu Bara itu kondusif bagi terciptanya keharmonisan atau kerukunan dalam proses interaksi kehidupan beragama? Pertanyaan ini relevan dibahas karena ada anggapan di sebagian kalangan bahwa semakin religius seseorang, maka semakin fanatik yang bersangkutan. Sikap fanatik tersebut pada gilirannya melahirkan sikap yang tidak toleran terhadap komunitas etnis dan agama lain. Apakah cara berpikir demikian dapat secara akurat menggambarkan komunitas Melayu Batu Bara?

Perlu dikemukakan bahwa menurut keterangan sejumlah informan, mayoritas masyarakat Melayu Muslim Batu Bara menganut paham keagamaan Ahl al-Sunnah wa al-Jamâ'ah (Aswaja); suatu corak pemahaman keislaman yang juga dianut oleh umumnya komunitas Muslim Batu Bara di tempat-tempat lain, dan bahkan dianut oleh mayoritas Muslim Indonesia. ${ }^{28}$ Paham keislaman ini secara teologis mengacu pada pemikiran Abu al-Hasan al-Ash'arî (dikenal dengan Ash'arîyah), sedangkan dalam hal ini aliran hukum mengacu pada tradisi empat imam mazhab, yakni Mâlikî, Ḥanafî, Shâfiîm dan Hanbalî.

Secara garis besar, pandangan keislaman yang dianut masyarakat Batu Bara membagi bidang interaksi menjadi dua: bablun minallah (hubungan dengan Allah) dan bablun minannas (hubungan dengan manusia). Sebagian informan berpandangan bahwa tidak ada salahnya untuk bersikap fanatik dalam urusan keagamaan, terutama menyangkut perkara ibadah dan ritual kepada Allah. Bila demikian, bagaimana kita harus berhubungan dengan orang yang berlainan paham keagamaan, baik intern umat Islam maupun dengan umat nonMuslim? Konsep yang lazim dijadikan pijakan oleh masyarakat Muslim Batu Bara adalah konsep nafsi-nafsi (masing-masing). Artinya, "kita tidak perlu mencampuri keyakinan orang, dan kita juga meminta orang tidak mengutak-atik keyakinan kita," demikian penjelasan seorang informan. Sedangkan menyangkut hubungan antarmanusia,

${ }^{28}$ Mukhlis, dkk. (Guru Agama), Wawancara, Lima Ralas 20 Oktober 2015. 
kita malah diperintahkan untuk berbuat baik kepada sesama manusia. Perbedaan keyakinan agama tidak menghalangi orang Muslim (Batu Bara) untuk menjalin kerjasama di bidang-bidang sosial dan kemanusiaan dengan etnik dan umat beragama lain.

Disamping konsep ini, sesungguhnya masyarakat Melayu Batu Bara juga memiliki suatu nilai kearifan yang menjadi pedoman dalam berinteraksi. Nilai tersebut, sebagaimana disebutkan di atas, dikemas dalam ungkapan "di mana bumi dipijak, di sana langit dijunjung". Yaitu, ketika kita mendatangi suatu tempat, kita harus menghormati dan sedapat mungkin menyesuaikan diri dengan tradisi setempat, sepanjang tradisi itu tidak bertentangan dengan keyakinan mendasar kita. Seandainya terjadi pertentangan, maka orang Batu Bara kembali menggunakan konsep nafsi-nafsi. Dengan kata lain, orang Melayu Batu Bara tidak mau turut campur urusan orang. Kalaupun mereka ingin melakukan perubahan, maka perubahan tersebut dilakukan tidak secara drastis, melainkan perlahan dan bertahap.

\section{Interaksi Sosial Keagamaan}

Hubungan etnik Melayu dengan etnik-etnik yang ada di Batu Bara dalam berinteraksi sosial—baik yang berasimilasi atas dasar kesamaan agama yang dianut (Islam) maupun yang tidak berasimilasimemberikan corak penampilan sebagai pemeluk Islam yang berinteraksi sosial berdasarkan atas nilai tradisi, adat dan budaya Melayu Batu Bara yang diwarnai agama Islam. Orientasi nilai membentuk pandangan dan sikap hidup. Ada beberapa orientasi nilai etnis Melayu yang penting di antaranya: 1) sederhana dalam penampilan hidup, tidak melampaui norma yang berlaku, 2) hutang dianggap menjadi beban, baik material maupun moral; 3) mempertahankan martabat dengan budi pekerti mulia; 4) keutamaan mengharap "berkah" dalam kepemilikan harta; 5) kejujuran sebagai harga diri yang utama; 6) persaudaraan sebagai suatu wujud kebersamaan dalam kehidupan; 7) bahasa dalam tutur kata (budi bahasa); 8) menghindari perselisihan; dan 9) tidak menonjolkan diri. ${ }^{29}$

Orientasi tata nilai tersebut di atas menunjukkan bahwa muatan agama Islam cukup kental memberikan warna dalam nilai yang dianut oleh masyarakat Batu Bara. Karena itu, jika ada pendatang etnis lain dari luar ke daerah Batu Bara yang agamanya sama dengan yang dianut dengan etnis Melayu di Batu Bara, maka akan mudah terjalin interaksi sosial, sebagaimana diungkapkan dalam lintasan sejarah

${ }^{29}$ UU Hamidy, Perantau Jawa di Daerah Rian (Pekanbaru: UIR Press, 1996). 
Melayu. Di sisi lain, saat yang datang para migran yang berbeda agama, maka memperlakukannya dengan "bijak" berdasar pada nilai adat, tradisi dan budaya. ${ }^{30}$

Interaksi sosial antar-etnis yang ada di daerah Batu Bara, berlangsung dalam kegiatan ekonomi, sosial, politik dan kehidupan keagamaan. Secara umum semua etnis yang ada di Batu Bara saling membutuhkan. Misalnya di bidang ekonomi, interaksi sosial antaretnis berlangsung antara pemilik usaha dengan pekerja, maupun para konsumen. Di sektor lain pun mereka berinteraksi dengan baik. Proses interaksi sosial ekonomi berjalan sesuai dengan kebutuhan, dan bersifat simbiosis mutualisme.

Proses jual beli dengan sistem "hutang" antara penjual dan pembeli dagangan, menjadi suatu model yang menjadi kesepakatan bersama. Pembeli dalam partai besar mengambil dagangan dari penjual dengan membayar sebagian harga, kemudian sisanya akan dibayar saat semua barang dagangan telah habis terjual dan akan mengambil yang baru. Berdasarkan pengakuan pedagang etnis Melayu, sistem tersebut sudah menjadi kelaziman. Yang dieksplorasi adalah kepercayaan dan kejujuran. Karena dalam tatanan nilai yang dianut, misalnya pada etnis Melayu, bahwa hutang adalah suatu yang akan dipertanggungjawabkan seseorang sampai di akhirat.

Melalui tatanan saling percaya dan mempertahankan serta menjunjung tinggi kejujuran, hubungan antar-etnis tidak hanya terbatas dalam kegiatan ekonomi, tetapi menyentuh semua aspek kegiatan sosial, politik, dan keagamaan, karena hal tersebut merupakan tuntunan dari ajaran Islam yang menjadi acuan dalam kehidupan. Demikian pula dalam kehidupan sosial, terlihat di

\footnotetext{
30 Masyarakat Melayu berpegang pada sistem nilai yang dapat dikelompokkan menjadi tiga, yaitu: pertama, sistem nilai yang mendasarkan pada agama Islam. Masyarakat menyadari nilai-nilai agung tersebut dan menjadikan acuan dalam kehidupan. Seseorang yang hidup dan kehidupannya berpedoman kepada nilai-nilai agung tersebut dipandang sebagai manusia yang bermartabat tinggi dan menjadi contoh dan teladan dalam kehidupan. Kedua, adalah sistem nilai yang berdasar pada adat. Sistem nilai tersebut diberikan oleh para pemangku adat untuk tujuan mengatur kehidupan sosial agar dapat berjalan dengan baik, damai dan harmoni, antarsesama manusia. Ketiga, sistem nilai tradisi adalah yang terkait dengan hubungan manusia dengan alam. Tengku M. Lah Husny, Lintasan Sejarah (Medan: B.P. Husny, 1975), 27; Tengku Luckman Sinar, Jati Diri Melayu (Medan: Majelis Adat Budaya Melayu Indonesia, 1994), 12; Mohamed Taib Osman, "Agama dan Kepercayaan Orang Melayu”, dalam Masyarakat Melayu: Struktur, Organisasi, dan Manifestasi (Kuala Lumpur: Dewan Bahasa dan Pustaka, 1989), 176.
} 
pemukiman-pemukiman penduduk, interkasi sosial berlangsung secara interaktif antar-warga dari berbagai etnis.

Bahkan dalam satu wilayah Dusun, tidak jarang ditemui kepala dusun dari etnis yang berbeda-beda, seperti kepala dusun dipegang oleh etnis, Melayu, Jawa, Batak, maupun Minang. Mereka dipilih secara mufakat dalam pemilihan yang dilakukan oleh para anggota masyarakat. Namun demikian, kepala dusun terpilih melakukan berbagai upaya penyelenggaraan pelayanan kepada warga bersamasama dengan tokoh masyarakat, termasuk dengan tokoh adat yang ada di wilayahnya. Cara demikian dinyatakan oleh tokoh-tokoh masyarakat dan adat yang terjadi dan berlangsung semenjak dahulu dan mentradisi dalam kehidupan.

Dalam kancah politik, terbuka kesempatan bagi etnis non-Melayu untuk menduduki posisi sebagai elite politik. Misalnya, karena dipandang memiliki kemampuan dan kecakapan dalam berorganisasi dan manajemen, seseorang akan memperoleh kesempatan yang sama tanpa melihat etnis atau asal daerahnya. Walaupun untuk hal-hal tertentu, seperti kepala daerah diakui ada kecenderungan lebih diutamakan putra daerah. Tetapi untuk pimpinan partai atau organisasi massa tertentu peluang untuk menjadi pimpinan terbuka sama untuk semua etnis.

\section{Penutup}

Masyarakat Kabupaten Batu Bara dapat dikategorikan pluralis. Umumnya dalam masyarakat yang plural rawan timbulnya konflik, terutama jika dipicu oleh masalah-masalah agama, seperti yang terjadi di beberapa tempat di Indonesia ini. Ternyata hal itu tidak terjadi di wilayah ini, walaupun penduduknya multietnik dan memeluk agama yang berbeda. Situasinya tetap harmonis, damai dan rukun. Keharmonisan itu ditandai dengan adanya keselarasan, kecocokan, atau tidak berselisih dan terpelihara pola-pola interaksi di antara berbagai komunitas pemeluk agama, dengan mencerminkan hubungan timbal balik dalam bentuk sikap saling menerima, mempercayai, menghormati dan menghargai, serta memaknai kebersamaan. Keharmonisan masyarakat Kabupaten Batu Bara ditunjukkan dengan adanya kesadaran masyarakat dalam memelihara kerukunan hidup, intensifikasi interaksi sosial sesama warga dengan berbasis kepada konservasi dan penadayagunaan kearifan budaya lokal. 
Artikel ini mendukung pendapat Mudler, harmoni berarti mengatasi perbedaan-perbedaan, bekerjasama, saling menerima, hati tenang dan hidup rukun. ${ }^{31}$ Demikian pula menurut Khalikin bahwa peran tokoh tampak dominan dalam membimbing, mengarahkan dan memberikan solusi bila terjadi perbedaan pendapat yang dapat mengganggu keharmonisan. ${ }^{32}$ Seperti halnya pendapat Hurriyah, bahwa pluralitas di wilayah itu ternyata tidak hanya dilihat dari perspektif keagamaan, tetapi juga internalisasi nilai-nilai budaya telah ikut mengambil posisi yang penting dalam masyarakat melalui budaya lokal. ${ }^{33}$ Sedangkan Ashutosh Varshney, dalam penelitiannya tentang Hindu dan Islam di India, menunjukkan adanya titik temunya tentang faktor yang dapat mencegah konflik, yaitu adanya ikatan kerjasama dalam bentuk asosiasi (associational forms engagement) dan adanya kegiatan hidup sehari (everyday forms engagement).

\section{Daftar Rujukan}

\section{A. Buku/Jurnal}

Ashutosh, Varshney. Konflik Etnis dan Peran Masyarakat Sipil Pengalaman India, terj. Siti Aisah dkk. Jakarta: Balai Litbang Agama, Departemen Agama, 2009.

Forum Komunikasi Umat Beragama Sumatera Utara, Tim. "Kerangka Acuan: "Dialog Urgensi Aktualisasi Pendidikan Multikultural dalam Membangun Kerukunan Antar Umat Beragama", Makalah disampaikan pada seminar Dialog Urgensi Aktualisasi Pendidikan Multikultural dalam Membangun Kerukunan Antarumat Beragama, di Medan, 17 Oktober 2009.

Hamidy, UU. Perantau Jawa di Daerah Riau. Pekanbaru: UIR Press, 1996.

Heriyah. "Kerukunan Umat Beragama di Desa Kotesan". Tesis-Sekolah Pascasarjana CRCS Universitas Gadjah Mada Yogyakarta.

\footnotetext{
31 Niels Mulder, Kebatinan dan Hidup Sehari-hari Orang Jawa: Kelangsungan dan Perubahan Kultural, terj. Alois A. Nugroho (Jakarta: Gramedia, 1984), 82.

32 Ahsanul Khalikin, Pandangan Pemuka Agama tentang Eksklusivisme Beragama di Indonesia (Jakarta: Puslitbang Kehidupan Keagamaan Badan Litbang dan Diklat Kementerian Agama RI. 2013); Ahsanul Khalikin, "Pandangan Pemuka Agama tentang Urgensi Pengaturan Hubungan Umat Beragama di Provinsi Bali", Harmoni: Jurnal Multikultural dan Multireligius, Vol. 14, No. 3 (September-Desember 2015), 75.

33 Heriyah, "Kerukunan Umat Beragama di Desa Kotesan" (Tesis--Sekolah Pascasarjana CRCS Universitas Gadjah Mada Yogyakarta), 32.

34 Varshney Ashutosh, Konflik Etnis dan Peran Masyarakat Sipil Pengalaman India, terj. Siti Aisah dkk. (Jakarta: Balai Litbang Agama, Departemen Agama, 2009), 9.
} 
Husny, Tengku M. Lah. Lintasan Sejarah. Medan: B.P. Husny, 1975.

Khalikin, Ahsanul. "Pandangan Pemuka Agama tentang Urgensi Pengaturan Hubungan Umat Beragama di Provinsi Bali", Harmoni: Jurnal Multikultural dan Multireligius, Vol. 14, No. 3, SeptemberDesember 2015.

Khalikin, Ahsanul. Pandangan Pemuka Agama tentang Eksklusivisme Beragama di Indonesia. Jakarta: Puslitbang Kehidupan Keagamaan Badan Litbang dan Diklat Kementerian Agama RI., 2013.

Kusnadi. "Masyarakat Tapal Kuda, Konstruksi Kebudayaan dan Kekerasan Politik", Jurnal Ilmu-Imu Humaniora, Vol. 2, No. 2, Juli, 2001.

Lubis, Nur Ahmad Fadhil. "Multikulturalisme dan Persinggungannya dengan Agama dan Umat Islam" dalam Jurnal Kerukunan: Kerukunan Berbasis Multukultural, Oktober-Desember 2008.

Mametzger, Lauraent. Kekuatan dan Kelemahan Orang Melayu: Suatu Pandangan Seorang Asing. Kuala Lumpur: Akademi Pengkajian Melayu University Malaya, 1994.

Mulder, Niels. Kebatinan dan Hidup Sehari-hari Orang Jawa: Kelangsungan dan Perubahan Kultural, terj. Alois A. Nugroho. Jakarta: Gramedia, 1984.

Osman, Mohamed Taib. "Agama dan Kepercayaan Orang Melayu", dalam Masyarakat Melayu: Struktur, Organisasi, dan Manifestasi. Kuala Lumpur: Dewan Bahasa dan Pustaka, 1989.

Pelly, Usman. "Siapakah Orang Melayu Itu?”, Republika, 27 Juli 2002. Ridwan, T. Amin. Budaya Melayu Menghadapi Globalisasi. Medan: USU Press, 2005.

Sinar, Tengku Luckman. Jati Diri Melayu. Medan: Majelis Adat Budaya Melayu Indonesia, 1994.

Takari, Muhammad dan Dewi, Heristina. Budaya Musik dan Tari Melayu Sumatera Utara. Medan: USU Press, 2008.

Tim Badan Pusat Statistik Kabupaten Batu Bara, Batu Bara dalam Angka 2015. Batu Bara: BPS Kabupaten Batu Bara, 2015.

\section{B. Wawancara}

Amir, Sulaiman Muhammad (Cendekiawan Melayu Batu Bara). Wawancara. Lima Puluh, Batu Bara 16 September 2015.

Effendi, Bachtiar (Wakil Ketua Pengurus Harian Forum Komunikasi Antar Lembaga Adat Kabupaten Batu Bara). Wawancara. Pantai Bunga 14 Oktober 2015. 
Habibi (penggiat budaya Melayu Batu Bara). Wawancara. Desa Lima Puluh Batu Bara 11 Oktober 2015.

Habibi. Wawancara. Lima Puluh 11 Oktober 2015.

Muchlis (Guru Agama). Wawancara. Lima Laras, Batu Bara, 15 September 2015.

Wawancara. Lima Laras, Batu Bara 16 Oktober 2015.

Mukhlis, dkk. (Guru Agama). Wawancara. Lima Ralas 20 Oktober 2015.

Sofyan, H. (Ketua Dewan Pertimbangan Forum Komunikasi Antarlembaga Adat Kabupaten Batu Bara). Wawancara. Tanjung Tiram 14 Oktober 2015.

Sulaiman Muhammad Amir (Cendekiawan Melayu Batu Bara). Wawancara. Lima Puluh, Batu Bara 18 September 2015. 